\title{
KIPRAH Al-WASHLIYAH DI KALIMANTAN SELATAN DI BIDANG PENDIDIKAN
}

\author{
Sarmiji Aseri dan Abu Bakar*
}

\begin{abstract}
Fatwa bukum Islam itu dapat berubah sebab berubahnya masa, tempat, situasi, dorongan dan motivasi. Fatwa yang dipahami sebagai jawaban resmi terhadap pertanyaan atau persoalan penting menyangkut kepercayaan atau bukum yang diberikan oleh seseorang atau suatu lembaga yang mempunyai otoritas untuk melakukannya,suatu bukum menurut Al Washliyah adalah hanya ulama-ulama terdabulu saja yang mampu menetapkannya, karena:"Tidak semua orang mempunyai kesanggupan mengeluarkan bukum dengan seorang diri dari Alquran dan hadis, karena untuk melaksankan pekerjaan tersebut harus memenubi berbagai persyaratan. Harus mengerti betul bahasa Arab, mempunyai perlengkapan tentang ilmu-ilmu yang diperlukan untuk memahami Alquran dan hadis, dan berbagai syarat lain yang diterangkan dalam kitab Usül al-Fiqh. Al Washliyah sebagai salab satu organisasi soal keagamaan di Indonesia mempunyai Anggaran Dasar Al Washliyah tentang bukum fikih disempurnakan dari "bermazhab Syafi'i" menjadi "Dalam iktikad dan bukum fikih bermazhab Alus Sunnah wal Jama'ah dengan mengutamakan mazhab Syafi'i”.
\end{abstract}

Kata-kunci: Al Washliyah, bermazhab Syafi'i', Tokoh Kalsel

\section{Pendahuluan}

Hukum Islam ada yang bersifat al-abkeàm al-syariyyah al-śäitah (hukumhukum yang satatis dan tidak berubah karena perubahan zaman, ruang dan waktu), karena masla $\underline{h} a h$ yang ada padanya bersifat langeng (up to date) karena datang langsung dari Allah swt. berupa Alquran dan Al-sunnah. Ada pula hukum Islam itu yang bersifat al-abkam al-syar'iyyah al-mutagayyirah wa al-mutatawirah (hukum-hukum yang berubah disebabkan perubahan zaman,

* Penulis adalah Dosen Luar Biasa (Sarmiji Aseri pada Fakultas Syariah) dan (Abu Bakar pada Fakultas Tarbiyah) IAIN Antasari Banjarmasin. 
waktu dan ruang), maslahah yang bersifat nisbi/bisa berubah, sementara, relative dan tak kekal (tidak up to date). ${ }^{1}$ Menurut Ibnu Qayyim al-Jauziyyah kaidah yang berbunyi:

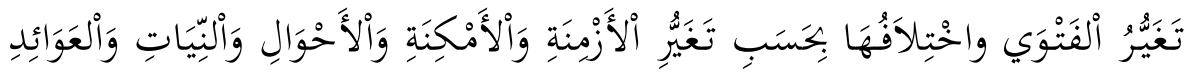

Artinya: "Fatwa bukum Islam itu dapat berubah sebab berubahnya masa, tempat, situasi, dorongan dan motivasi".

Fatwa yang dipahami sebagai jawaban resmi terhadap pertanyaan atau persoalan penting menyangkut kepercayaan atau hukum yang diberikan oleh seseorang atau suatu lembaga yang mempunyai otoritas untuk melakukannya. ${ }^{2}$ Bentuk fatwa, termasuk di Indonesia menunjukkan kreatifitas yang luar biasa antara teks dan realitas sosial kekinian. ${ }^{3}$ Organisasi sosial keagamaan Islam di Indonesia seperti Muhammadiyah, Al Jam'iyatul Washliyah (selanjutnya disebut $\mathrm{Al}$ Washliyah),

Tahun 1928 para pelajar kelas tinggi MIT $^{4}$ yang berumur sekitar 20-25 tahunan, ${ }^{5}$ membentuk sebuah kelompok diskusi dengan tujuan awal mendiskusikan pelajaran mereka, ${ }^{6}$ dengan nama "Debating Club". Pemberian nama Debating Club hasil inisiatif mereka, dengan maksud mereka ingin berdiri sejajar dengan rekan-rekan pelajar Islam yang belajar di sekolah Belanda. ${ }^{8}$ Dalam perkembangannya kelompok ini tidak hanya mendiskusikan pelajaran, juga membahas persoalan masalah-masalah sosial kemasyarakatan yang

${ }^{1}$ Ahmad Munif Suratmaputra, Filsafat Hukum Islam, al Ghazali Mashlaba Mursalah dan Relevansinya dengan Pembaharuan Hukum Islam, (Jakarta: Pustaka Firdaus, 2002), h. 60.

${ }^{2}$ Ahmad Munif Suratmaputra, Filsafat Hukum Islam... , h. 21.

${ }^{3} \mathrm{Ahmad}$ Munif Suratmaputra, Filsafat Hukum Islam..., h. 14.

${ }^{4}$ Seperti Ismail Banda, Abdurrahman Syihab, M. Arsyad Talib Lubis, Adnan Noer, M. Ja'coeb dan lain-lain,

${ }^{5}$ Tim Pelaksana Proyek Penulisan Buku 70 Tahun Al-Washliyah, Al Jam'yatul Washliyah, Memasuki Millenium III, Kado Ulang Tabun Al Washliyab ke-69 Tabun 1999, Jakarta: PB Al Washliyah, 1999), h. 17. Buku ini walau dalam maklumat halaman i tidak boleh dijadikan rujukan namun oleh penulis data ini dianggap cukup valid atau diterima sebagai data ilmiah.

${ }^{6}$ Chalidjah Hasanudin, Ibid., h. 34.

${ }^{7}$ Pendirinya adalah Abdurrahman Syihab. Chalidjah Hasanudin, Ibid. h. 38.

8Ibid., h. 35. 
menarik untuk dibahas, misalnya tentang persatuan umat Islam dalam paham keagamaan dan masalah dakwah Islam.'

Berdasarkan buku Seperempat Abad Al-Washliyah, pertemuan pertama, pada awal bulan Oktober 1930, bertempat di rumah H.M. Yusuf Ahmad Lubis, Gelugur Medan, di bawah pimpinan Abdurahman Syihab dilangsungkan pertemuan yang dihadiri oleh H.M. Yusuf Ahmad Lubis, Adnan Noer, M. Isa dan lain-lain dengan maksud pertemuan itu adalah membicarakan bagaimana cara memperbesar Perkumpulan Pelajar tersebut. Seminggu kemudian, pada pertemuan kedua, bertempat di rumah Abdurrahman Syihab di Petisah Medan, yang dihadiri oleh Abdurrahman Syihab, Ismail Banda, H.M. Yusuf Ahmad Lubis, Adnan Noer, A. Wahab dan M. Isa, dengan kesepakatan untuk membangun suatu perkumpulan yang lebih besar dengan usaha yang lebih luas. Untuk membawa para guru dan pelajar Islam lainya direncanakan untuk mengadakan pertemuan yang lebih besar. ${ }^{10}$

Pada tanggal 9 Rajab $1349 \mathrm{H}$ atau 30 Nopember 1930 di Medan, ${ }^{11}$ jalan Hindu Medan, ${ }^{12}$ dengan resmi didirikan organisasi yang diberi nama "Al Jami'atul Washliyah" yang berarti perhimpunan yang mengembangkan dan mempertalikan sesama umat Islam, ${ }^{13}$ sebagai cerminan dari usaha organisasi ini, selanjutnya disebut $\mathrm{Al}$ Washliyah. Nama ini diberikan oleh Syekh H. Muhammad Yunus, ${ }^{14}$ Pimpinan MIT Medan, salah seorang tokoh ulama bermazhab Syafi'i yang independen berada di luar birokrasi kerajaan. ${ }^{15}$

${ }^{9}$ Tim Penulis IAIN Syarif Hidyatullh, Ensiklopedi Islam Indoensia, Jilid 3, Jakarta: Djambatan, 2002), Cet. Ke-2, h. 1267.

${ }^{10}$ Tim Pelaksana Proyek Penulisan Buku 70 Tahun Al-Washliyah, Op. Cit., h. 16.

${ }^{11}$ Pengurus Besar Al Washliyah, Anggaran Dasar dan Anggaran Rumah Tangga Al Jami'atu; Wabliyah Periode 2003-2008, (Jakarta: t.p, 2003), h. 4.

${ }^{12}$ Artikel dari Abdul Rasyid Pulungan, Barabai, Hulu Sungai Tengah, Kalmantan Selatan, h. 1 .

${ }^{13}$ M. Hasbullah Thaib, Loc. Cit.

${ }^{14} \mathrm{~PB}$ Al Washliyah, Op. Cit., h. 2.

${ }^{15}$ Kerajaan di Medan yang ada pada waktu itu ialah kerajaan atau kesultanan Deli. Chalidjah Hasanudin, Loc. Cit., h. 4. 


\section{Al Washliyah di Kalimantan Selatan}

1. Sejarah Masuk Al Washliyah di Kalimantan Selatan

Organisasi sosial keagamaan Al Washliyah di Kalimantan Selatan di bawa pertama kali tahun 1955 oleh M. Daud Yahya, ${ }^{16}$ salah seorang anggota PP Gerakan Pemuda Al Washliyah di Amuntai. ${ }^{17}$ Berdasarkan wawancara dengan Jakpar Tahlib dan Pulungan Organisasi Al Washliyah di Kalimantan Selatan pertama kali ada pada tahun 1963-an beralamat di Jalan Andalas Banjarmasin yang dibawa oleh M. Daud Yahya. ${ }^{18}$

Berdasarkan data di atas, ada pernyataan "pertama kali", kedua data tersebut benar, akan tetapi menurut hemat penulis, maksudnya pertama kali di Wilayah Kalimantan Selatan adalah tahun 1955 di Amuntai, sedangkan pertama kali tahun 1963-an itu keberadaan al Washliyah di Banjarmasin.

2. Perkembangan Al Washliyah di Kalimantan Selatan

a. Banjarmasin

Di Banjarmasin organisasi Al Washliyah berkembang pada tahun 1963 di Jalan Andalas.

Tokoh-tokoh yang mempunyai andil besar dalam perkembangan $\mathrm{Al}$ Washliyah di Banjarmasin, antara lain: $\mathrm{KH}$ Abdurrahman Ismail, $\mathrm{KH}$ Hanafi Gobit, KH Mastur Zahri, ${ }^{19}$

Sesuai dengan kiprah Al Washliyah di bidang pendidikan, dakwah dan sosial. Hal ini dapat dilihat pada keberadaan lembaga pendidikan yang antara lain: ${ }^{20}$

1). Perguruan Al Irtiqaiyah, Jalan Pemurus Banjarmasin Selatan, didirikan oleh KH Bakri.

2). Perguruan Al Inayah, Jalan Belitung Darat, Banjarmasin Barat, didirikan oleh KH. Nayan bin Nashim. Diteruskan oleh KH. Achmad Nudja H. Saal, sekarang ini pimpin oleh H. Hasan Basri H. Nayan.

\footnotetext{
${ }^{16}$ Kelahiran Medan. Pernah menjadi Kepala PGA dan Kepala Depag Kal Sel.

${ }^{17}$ Buku 1/4 Abad Al Washliyah terbitan Tahun 1955, dokumen pada Sarmiji Aseri. Dia Pemerhati Al Washliyah, Wawancara Pribadi Abu Bakar, Banjarmasin, Rabu, 5 Mei 2010.

${ }^{18}$ Jakpar Thalib dan Pulungan, Keduanya Pengurus Al Washliyah di Barabai, Wawancara Pribadi Juairiah, diolah Abu Bakar, Kamis, 6 Mei 2010.

${ }^{19}$ Sarmiji Aseri. Pemerhati Al Washliyah, Wawancara Pribadi Abu Bakar, Banjarmasin, Selasa, 4 Mei 2010.

${ }^{20} \mathrm{Ibid}$.
} 
3). Perguruan Al Abadiyah Al Washliyah (MTs Al Abadiyah Al Washliyah), Komplek Zafri Zam Zam Banjarmasin, didirikan oleh KH Mulkani. ${ }^{21}$

4). STAI Al Jami, Jalan Masjid Al Jami Banjarmasin, didirikan oleh Yayasan Pengabdian Banjarmasin terdiri dari tokoh di antaranya: Drs. H. Imansyah Azis, KH Husni Nafarin, MA, KH. M. Qathalani, MA, KH Abdurrahim Yasin, Lc.

b. Kabupaten Banjar

Kabupaten Banjar dengan ibukota Martapura, organisasi Al Washliyah yang nampak keberadaanya di daerah desa Pematang Hambawang kecamatan Astambul. Di daerah ini berdiri perguruan pendidikan dengan nama Perguruan Al Washliyah, dengan jenjang pendidikan TK, MI, dan MTs. Perguruan ini sering dikunjungi oleh tokoh-tokoh $\mathrm{Al}$ Washliyah seperti $\mathrm{KH}$ Nayan bin Nashim, KH Muhammd Saubri H. Saal, KH M. Yuseran Salman, ${ }^{22}$ KH. Kamrani Buseri. KH. Muh. Alwi Mahbar. ${ }^{23}$

Selain di desa Pematang Hambawang, organisasi Al Washliyah juga berkembang di desa Rumpiang Jambu Burung Gambut dengan berdirinya Pondok Pesantren Ibnul Amin pimpinan KH. M. Zuhri. ${ }^{24}$

c. Kabupaten Hulu Sungai Tengah

Di Kabupaten HST tepatnya di Barabai berdiri Sekolah Tinggi Agama Islam (STAI) Al Washliyah. Ketua umum Al Washliyah HST adalah Jakpar Thalib. ${ }^{25}$

3. Kepengurusan Al Washliyah Kalimantan Selatan

Pergantian kepengurusan organisasi sosial keagamaan Al Washliyah berdasarkan AD-RT dilakukan setiap 5 tahun sekali.

Dari hasil muktamar yang baru saja dilaksanakan pada tahun 2010 ada perubahan dalam AD-RT bahwa ketua Al Washliyah tidak boleh ikut menjadi

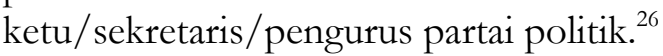

Kepengurusan Al Washliyah Kalimantan Selatan, yaitu:

a. KH. M. Daud Yahya, periode I

b. KH. Mastur Zahri, periode II

\footnotetext{
${ }^{21} \mathrm{KH}$. Mulkani ini mempunyai hubungan khusus dengan KH. M. Daud Yahya. Ibid.

${ }^{22} \mathrm{KH}$. M. Yuseran Salman, melakukan kunjungan berkala ke daerah ini.

${ }^{23}$ Sarmiji Aseri, Ibid.

${ }^{24} \mathrm{KH}$. M. Zuhri mempunyai anak yang sukses di Banjarmasin, antara lain: Isa Anshari (Mantan PD III Fakultas Tarbiyah), Husnul Yaqin (Asisten Direktur PPs IAIN Antasari).

${ }^{25}$ Sarmiji Aseri, Ibid.

${ }^{26}$ Jakpar Thalib dan Pulungan, Ibid.
} 
c. KH Prof Dr. M. Yuseran Salman, Lc, periode III

d. Drs. H. Thaberani Djauhar, periode IV

e. Drs. H. Mulkani, periode V, 1995-2007

f. Prof. Dr. H. Kamrani Buseri, MA, ${ }^{27}$ periode VI, 2007- sekarang. ${ }^{28}$

\section{Metode Fatwa Dewan Fatwa Al Washliyah dan Aplikasinya}

\section{Metode Fatwa Dewan Fatwa Al Washliyah}

Anggaran Dasar Al Washliyah menyatakan sistem bermazhab Syafi'i dan berakidah Ahlussunnah wal jama'ah, yang pada waktu itu dengan cepat mendapat dukungan dari masyarakat luas, karena masyarakat pada waktu itu menyatakan diri sebagai pengikut mazhab Syafi'i. Di Sumatera Utara Medan berkembang pula organisasi Muhammadiyah yang secara tegas menolak taqlid dan tidak bermazhab, oleh karena itu organisasi ini sulit berkembang pesat. ${ }^{29}$

Pada Mukhtamar Al-Jam‘iyatul Washliyah XVIII di Bandung 25-30 Nopember 1997), Anggaran Dasar Al Washliyah tentang hukum fikih disempurnakan dari "bermazhab Syafi'i" menjadi "Dalam iktikad dan hukum fikih bermazhab Alus Sunnah wal Jama'ah dengan mengutamakan mazhab Syafi'i". Pedoman Penetapan Fatwa Al-Washliyah diformulasikan sebagai berikut:

a. Fatwa harus berdasarkan kepada salah satu dalil hukum Islam, yaitu Alquran, Sunnah, ijmā', qiyās, al-istihbān, maslabah mursalah, al-urf, al-istishab, syariat umat terdahulu dan mazhab sahabat.

b. Metode yang digunakan dalam menetapkan fatwa adalah metode istinbāt yang digunakan para ulama mazhab dari kalangan Ahlussunnah wal jama'ah.

Metode Penetapan Fatwa yang dijadikan pedoman Dewan Fatwa Al Washliyah Mukhtamar Al-Jam‘iyatul Washliyah XVIII di Bandung 25-30 Nopember 1997, yaitu:

\footnotetext{
${ }^{27}$ Terpilih berdasarkan hasil silaturrahmi di Banjarmasin 2007, dan baru dilantik tahun 2009 di Auditorium IAIN Antasari Banjarmasin..

${ }^{28}$ Sarmiji Aseri, Ibid.

${ }^{29}$ Nina M. Armandi (editor), Ensiklopedi Islam, (Jakarta: Ichtiar Baru van Hoeve, 2005), h. 293.

${ }^{30}$ Dewan Fatwa Al-Jam‘iyatul Washliyah, Hasil-Hasil Sidang Dewan Fatwa Al-Jam‘iyatul Washliyah, (Medan: Universitas Muslim Nusantara, 1998), h. 1-2.
} 
a. Pada dasarnya, fatwa yang dikeluarkan oleh Dewan Fatwa adalah menurut mazhab Syafi'i dalam kita-kitab mu'tabarah dengan ketentuan di bawah ini:

1) Mengenai maslah yang ketentuannya ditemukan pada ibarah kitab dan tentang masalah tersebut hanya satu qawl/wajah, fatwa ditetapkan menurut qawl/wajah tersebut.

2) Mengenai masalah yang ketentuan hukumnya ditemukan pada 'ibarah kitab dengan lebih daripada saru qawl/wajah, fatwa ditetapkan menurut hierarki sebagai berikut:

a) Pendapat yang disepakati oleh An-Nawawi dan Ar-Rafi'i.

b) Pendapat yang ditetapkan oleh An-Nawawi saja.

c) Pendapat yang ditetapkan oleh Ar-Rafi'i saja.

d) Pendapat yang di-tarjīh oleh mayoritas ulama.

e) Pendapat yang di-tarjīh oleh ulama yang terpandai.

f) Pendapat yang di-tarjī $\underline{h}$ oleh ulama yang paling warak.

g) Pendapat yang di-tarjīh oleh ulama atau belum ditemukan tarjīh terhadapnya dipilih melalui tarjī $\underline{j}$ jam 'iy .

3) Mengenai kasus atau masalah yang ketentuan hukumnya tidak ditemukan dalam kitab, fatwa ditetapkan melalui ilhäq masalah kepada nazir-nya.

4) Mengenai kasus atau masalah yang hukumnya dalam mazhab Syafi'i dalam kondisi tertentu, ta' $a \dot{2} \dot{z} u r$ atau $t^{6}$ assur untuk diamalkan, fatwa dapat ditetapkan dengan melakukan ikhtiyar terhadap salah satu qawl/wajah dalam mazhab Syafi'i atau pendapat mazhab di luar Syafi'i dari kalangan Ahlussunnah wal jama'ah.

5) Mengenai kasus atau masalah yang ketentuan hukumnya tidak ditemukan dalam kitab dan tidak mungkin dilakukan illpaqq, fatwa ditetapkan melalui ijtihäd jama'i iy. ${ }^{31}$

\section{Dinamika Pemahaman Istinbāt Hukum}

Al Washliyah dan Dewan Fatwa sejak berdirinya telah menetapkan metode fatwa mengikuti mazhab Syafi'i dengan herarkinya yaitu Alquran, hadis, ijmā' dan qiyās. Oleh karena itu bagi $\mathrm{Al}$ Washliyah sumber hukum utama adalah Alquran dan hadis, setelah itu ijmā' di kalangan sahabat Rasulullah saw., dan

${ }^{31}$ Ibid. 
terakhir menggunakan metode fatwa berdasarkan ijtihäd dengan mengandalkan pemikiran/ra'yu. ${ }^{32}$

Al Washliyah dalam perjalanan sejarahnya menyatakan diri untuk bermazhab Syafi'i, akan tetapi setelah Muktamar ke-18 di Bandung, paham itu lebih terbuka dengan pernyataan fikihnya bermazhab Ahlussunnah wal Jama'ah dengan mengutamakan mazhab Syafi'i, oleh karena itu tema pokok penetapan hukum Al Washliyah adalah ijtihad dan mengutamakan mazhab Syafi'i. Ijtihad dalam menetapakan suatu hukum menurut Al Washliyah adalah hanya ulamaulama terdahulu saja yang mampu menetapkannya, karena: "Tidak semua orang mempunyai kesanggupan mengeluarkan hukum dengan seorang diri dari Alquran dan hadis, karena untuk melaksankan pekerjaan tersebut harus memenuhi berbagai persyaratan. Harus mengerti betul bahasa Arab, mempunyai perlengkapan tentang ilmu-ilmu yang diperlukan untuk memahami Alquran dan hadis, dan berbagai syarat lain yang diterangkan dalam kitab Usül al-Fiqh." 33

Pada prinsipnya organisasi ini tidak menolak ijtihad, akan tetapi karena belum mampu mencapai taraf penguasaan dan pendalam ilmu, di mana pendukung organisasi ini masih dalam taraf belajar, dengan harapan adanya majelis ini muncul kader ulama di kalangan mereka sendiri. Organisasi ini telah berketetapan bahwa paham dalam fikih yang mereka anut adalah paham mazhab Syafi'i, sehingga mereka lebih mudah mengeluarkan fatwa berdasarkan paham mazhab Syafi'i tersebut. ${ }^{34}$ Berbeda dengan Muhammadiyah yang hanya mengakui Alquran dan hadis sebagai sumber hukum dan menolak taqlid. Taqlìd inilah yang menyebabkan manusia tidak mampu menggunakan akal, sehingga timbul paham jumüd (baku). Paham ini mengakibatkan manusia tidak mampu mengikuti perkembangan zaman, karena menganggap pintu ijtihad telah tertutup. ${ }^{35}$ Menurut Deliar Noer, pengakuan tentang ijtihad dan kembali kepada Alquran dan hadis sebagai sumber hukum tidak datang begitu saja,

${ }^{32}$ Mulkani, Penasehat Wilayah Al Washliyah Kal-Sel, Wawancara Pribadi, Banjarmasin, Senin, 11 Agustus 2008.

${ }^{33}$ Chalidjah Hasanudin, Al-Jam'iyatul Washliyah 1930-1942, Api dalam Sekam di Sumatera Timur, (Bandung: Pustaka, 1988), h. 104.

${ }^{34}$ Nina M. Armandi (editor), Ensiklopedi Islam, (Jakarta: Ichtiar Baru van Hoeve, 2005), h. 293.

${ }^{35}$ PP. Muhammadiyah, Dasar-dasar untuk Memahami Urusan Tariih, (Yogyakarta: Percetakan Muhammadiyah, 1982), h. 45, dalam M. Hasbullah Thaib, Universitas Al Washliyah Medan, Lembaga Pengkaderan Ulama di Sumatera Utara, (Medan: Universitas Al Washliyah, 1993), h. 56 . 
melainkan berangsur-angsur, terkadang disebabkan oleh tantang yang datang dari golongan tradisi, sebagai contoh di Minangkabau, taqlid dilakuan oleh golongan adat, sedangkan imam pendiri mazhab tetap dihormati sebagai mujtahid.$^{36}$ Orang yang mengikuti hukum yang difatwakan oeleh ulama tersebut dinamakan bermazhab, jika yang diikuti fatwa Syafi'i, maka disebut dengan nama bermazhab Syafi'i.

Mengikuti anggaran dasar Al Washliyah pada muktamarnya yang ke-18 menyebutkan: hukum fikih disempurnakan dari "bermazhab Syafi'i" menjadi "Dalam iktikad dan hukum fikih bermazhab Ahlussunnah wal Jama'ah dengan mengutamakan mazhab Syafi'i", ${ }^{37}$ Arti bermazhab Syafi'i pada anggaran dasar tersebut adalah:

1. Segala sesuatu usaha yang digerakan atas nama organisasi atau turut serta dalam pembahasan suatu masalah harus berlaku dalam batas-batas hukum fiqih mazhab Syafi'i.

2. Segala sesuatu perselisihan yang terjadi dalam organisasi ini menyangkut ketentuan hukum fiqih haruslah diputuskan dengan mengutamakan mazhab Syafi'i. ${ }^{38}$

Pernyataan ini harus ditafsirkan dengan maksud mempertegas rujukan dalam pelaksanaan hukum Islam, agar tidak terjadi kesalahpahaman dan kesimpangsiuran dalam mempersatukan potensi-potensi yang sepaham dalam memperjuangkan kepentingan umat Islam seluruhnya. ${ }^{39}$ Kemudian pernyataan "mengutamakan mazhab Syafi'i" tidak berarti membatasi anggotanya untuk melihat dan menelaah mazhab lain dalam memutuskan suatu hukum Islam demi kepentingan pribadinya. ${ }^{40}$

Latar belakang sejarah menyebutkan para tokoh pendiri Al Washliyah dan pemberi nama Al Jamiiyatul Washliyah yaitu Syekh Muhammad Yunus bermazhab Syafi'i, dengan tujuan untuk memajukan, mementingkan dan menambah tersiarnya agama Islam, serta organisasi ini terbuka bagi orang

${ }^{36}$ Deliar Noer, Gerakan Modern Islam di Indonesia 1900-1942, (Jakarta: PT Pustaka LP3ES, 1996), Cet. Ke-8, h. 11 dan 109.

${ }^{37}$ Dewan Fatwa Al-Jamiyatul Washliyah, Laporan Hasil-Hasil Sidang Dewan Fatwa Al-jam'iyatul Washliyah, (Medan, Universitas Muslim Nusantara, 1998), h. 1-2.

${ }^{38}$ Artikel dari Ja'fat Thalib, Barabai, Hulu Sungai Tengah, Kalimantan Selatan, h. 10.

${ }^{39}$ Tim Pelaksana Proyek Penulisan Buku 70 Tahun Al-Washliyah, Al Jam'yatul Washliyah, Memasuki Millenium III, Kado Ulang Tabun Al Washliyah ke-69 Tabun 1999, (Jakarta: PB Al Washliyah, 1999), h. 55.

${ }^{40} \mathrm{Ibid}$. 
Islam yang bermazhab Syafi'i ${ }^{41}$ Dengan kondisi masyarakat pada waktu itu yang meyatakan diri mereka bermazhab Syafi'i secara antusias mendukung $\mathrm{Al}$ Washliyah. ${ }^{42}$ Ikatan sejarah inilah yang tidak dapat melepaskan Al Washliyah untuk selalu mengutamakan mazhab Syafi'i. Menurut hemat penulis dengan analisa sederhana, apabila Al Washliyah meninggalkan mazhab Syafi'i, maka ia bukan lagi organisasi Al Wahliyah. ${ }^{43}$

Al Washliyah yang mengutamakan mazhab Syafi'i, berpedoman pada kaidah-kaidah fiqb: ${ }^{44}$

1. Membuat sesuatu yang baru, dengan kaidah fiqh

Artinya: "Yang sudab dikerjkan tidak dikerjakan lagi"

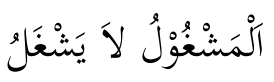

2. Capailah target walau tidak seratus persen dengan berusaha secara maksimal

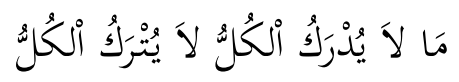

Artinya: "Kalau tidak tercapai semua jangan tinggalkan semua"

3. Pelajari situasi dan kondisi setempat dengan keahlian menempatkan diri, serta jangan lupa program

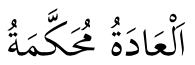

Artinya: "Adat setempat dijadikan bukum"

4. Bersihkan ibadah dari khuräfat seperti yang ditegaskan Imam Syafi'i

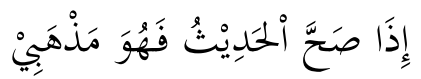

Artinya: "Kalau hadis itu sabizh itulah maşbabku"

${ }^{41}$ Ppipa washliyah@yahoo.com. Didown load pada 18 Juli 2008.

${ }^{42}$ Nina M. Armandi (editor), Loc. Cit.

${ }^{43}$ Amir Syarifuddin, Meretas Kebekuan Ijtihäd, Isu-Isu Penting Hukum Islam Kontemporer di Indoensia, (Jakarta: PT Ciputat Press, 2005), Cet. Ke-2, h. 29 dan 80.

${ }^{44}$ M. Ridwan Ibrahim Lubis, Kepribadian Anggota dan Pengurus Al Washliyah, Jakarta: PP HIMMHA, 1994), Cet. Ke-1, h. 25-26. Mulkani, loc. cit 


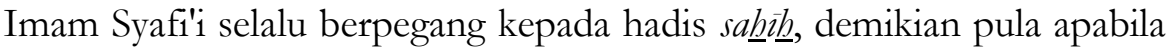
Al Washliyah ingin mengeluarkan fatwa selalu mengutamakan mazhab Syafi'i. Dalam praktik Al Washliyah tidak mewajibkan anggotanya harus beribadah menurut mazhab Syafi'i. ${ }^{45}$

\section{Contoh Fatwa Al Washliyah ${ }^{46}$}

Dewan Fatwa Al Washliyah mengeluarkan fatwa tentang hukum kawin antara muslim dan bukan muslim di catatan sipil pada tahun 1988 dengan dasar dalilnya adalah QS. Al-Baqarah (2): 221, QS. Al-Mumtabanah (60): 10, QS. Al-Mäidah (5): 5, dan mengambil dasar hukum dari kitab I'ānah al-tälibin, juz 3, h. 344 bahwa "Dan syarat boleh menikahinya jika dia Israiliyah bahwa tidak diketahui masuk awal nenek-neneknya di dalam itu agama setelah nāsakhnya dan peneyelewengannya, dan jika adalah dia yang bukan Israiliyah bahwa diketahui masuk awal nenek-neneknya didalam agama itu sebelum nāsakhnya dan peneyelewengannya".

Fatwanya adalah perkawinan muslim dengan yang bukan muslim baik di Catatan Sipil maupun di tempat-tempat lainnya dipandang dari hukum Islam tidak sah. Fatwa ini ditambah dengan akibat dari kawin beda agama seperti: Pertama, bergaul hidup serumahtangga dengan perkawinan tersebut adalah pergaulan diluar perkawinan Islam. Kedua, bila terjadi percampuran dan hubungan suami isteri sebagai akbat dari perkawainan itu ia dianggap zina. Ketiga, anak yang lahir dināsabkan kepada ibunya, bagi ayahnya tidak ada nāsab, tidak ada saling mewarisi, tidak berhak jadi wali nikah, dan wali nikah anak tersebut adalah hakim.

Penghalalan kawin beda agama bagi Dewan Fatwa Al Washliyah dengan syarat Ahlul Kitabi tersebut diketahui bapak-bapak yang pertama kali dalam agama itu sebelum mansükh dansebelum adanya perubahan. ${ }^{47}$ Akan tetapi syarat itu sulit untuk dilaksanakan, maka hukum kawin beda agama itu haram.

\footnotetext{
${ }^{45}$ M. Ridwan Ibrahim Lubis, Kepribadian Anggota dan Pengurus Al Washliyah, (Jakarta: PP HIMMHA, 1994), Cet. Ke-1, h. 25-26.

${ }^{46}$ Diolah dengan hasil wawancara dengan Suyuti Pulungan, Mulkani.

47 PB Al Ja'iyatul Washliyah, Keptusan-Keputusan Dewan Fatwa, Penasehat dan Pertimbangan Pengurus Besar Al Jam'iyatul Washliyah, (Cikopo: PB. Washliyah, 1988), h. 3-4.
} 


\section{Penutup}

Al Washliyah berdiri sejak 1930 di Medan dan masuk ke Kalimantan Selatan mulai tahun 1955 di bawa oleh M. Daud Yahya, salah seorang anggota PP Gerakan Pemuda Al Washliyah di Amuntai. Perkembangannya di KalSel terutama di Banjarmasin, Martapura, dan HST. Bergerak khusus di bidang pendidikan, dakwah dan sosial.

Al Washliyah sebagai salah satu organisasi sosial keagamaan di Indonesia mempunyai Anggaran Dasar Al Washliyah tentang hukum fikih disempurnakan dari "bermazhab Syafi'i" menjadi "Dalam iktikad dan hukum fikih bermazhab Alus Sunnah wal Jama’ah dengan mengutamakan mazhab Syafi'i”.

Arti bermazhab Syafi'i pada anggaran dasar tersebut adalah segala sesuatu usaha yang digerakan atas nama organisasi atau turut serta dalam pembahasan suatu masalah harus berlaku dalam batas-batas hukum fiqih mazhab Syafi'i. Segala sesuatu perselisihan yang terjadi dalam organisasi ini menyangkut ketentuan hukum fiqih haruslah diputuskan dengan mengutamakan mazhab Syafi'i. 


\section{Daftar Pustaka}

Ahmad Munif Suratmaputra, Filsafat Hukum Islam, al Ghazali Mashlaha Mursalah dan Relevansinya dengan Pembaharuan Hukum Islam. Jakarta, Pustaka Firdaus, 2002.

Amir Syarifuddin, Meretas Kebekuan Ijtihäd, Isu-Isu Penting Hukum Islam Kontemporer di Indoensia. Jakarta, PT Ciputat Press, 2005.

Artikel dari Abdul Rasyid Pulungan, Barabai, Hulu Sungai Tengah, Kalimantan Selatan.

Artikel dari Ja'fat Thalib, Barabai, Hulu Sungai Tengah, Kalimantan Selatan.

Buku 1/4 Abad Al Washliyah terbitan Tahun 1955, dokumen pada Sarmiji Aseri.

Chalidjah Hasanudin, Al-Jam'iyatul Washliyah 1930-1942, Api dalam Sekam di Sumatera Timur. Bandung, Pustaka, 1988.

Deliar Noer, Gerakan Modern Islam di Indonesia 1900-1942. Jakarta, PT Pustaka LP3ES, 1996.

Departemen Agama RI, Al Qur'an dan Terjemahnya. Jakarta, Yayasan Penyelenggara Penterjemah/Pentafsir Alqur'an, 1990.

Dewan Fatwa Al-Jam'iyatul Washliyah, Hasil-Hasil Sidang Dewan Fatwa Al-Jam 'iyatul Washliyah. Medan, Universitas Muslim Nusantara, 1998.

Dewan Fatwa Al-Jam'iyatul Washliyah, Laporan Hasil-Hasil Sidang Dewan Fatwa Al-Jam'iyatul Washliyah. Medan, Universitas Muslim Nusantara, 1998.

Jakpar Thalib dan Pulungan, Keduanya Pengurus Al Washliyah di Barabai, Wawancara Pribadi Juairiah, diolah Abu Bakar.

M. Hasbullah Thaib, Universitas Al Washliyah Medan, Lembaga Pengkaderan Ulama di Sumatera Utara. Medan, Universitas Al Washliyah, 1993. 
M. Ridwan Ibrahim Lubis, Kepribadian Anggota dan Pengurus Al Washliyah. Jakarta, PP HIMMHA, 1994.

Muhammad Asywadie Syukur, Pengantar Ilmu Fikih dan Ushul Fikih. Surabaya, PT Bina Ilmu, 1990.

Mulkani, Penasehat Wilayah Al Washliyah Kal-Sel, Wawancara Pribadi, Banjarmasin.

Nina M. Armandi (editor), Ensiklopedi Islam. Jakarta, Ichtiar Baru van Hoeve, 2005.

PB Al Ja'iyatul Washliyah, Keptusan-Keputusan Dewan Fatwa, Penasehat dan Pertimbangan Pengurus Besar Al Jam'iyatul Washliyah. Cikopo, PB. Washliyah, 1988.

Pengurus Besar Al Washliyah, Anggaran Dasar dan Anggaran Rumah Tangga Al Jami'atu; Wabliyah Periode 2003-2008. Jakarta, t.p, 2003.

Ppipa_washliyah@yahoo.com.

Tim Pelaksana Proyek Penulisan Buku 70 Tahun Al-Washliyah, Al Jam'yatul Washliyah, Memasuki Millenium III, Kado Ulang Tabun Al Washliyah ke-69 Tahun 1999. Jakarta, PB Al Washliyah, 1999.

Tim Penulis IAIN Syarif Hidyatullh, Ensiklopedi Islam Indoensia, Jilid 3. Jakarta, Djambatan, 2002. 